\title{
ANALISIS PENGHINDARAN PAJAK YANG DIPENGARUHI TINGKAT PROFITABILITAS
}

\author{
Sri Damayanti ${ }^{1}$, Sri Dewi Anggadini ${ }^{2 *}$, Ari Bramasto ${ }^{3}$ \\ ${ }^{1}$ Institut Agama Islam Sholahuddin Al-Ayyubi, ummijauhar@gmail.com \\ ${ }^{2}$ Universitas Komputer Indonesia, sri.dewi@email.unikom.ac.id(Corresponding Author) \\ ${ }^{3}$ Universitas Langlangbuana, arya_bravo@ymail.com
}

\begin{abstract}
ABSTRAK
Penelitian ini dilakukan untuk mengetahui pengaruh Profitabilitas terhadap Penghindaran Pajak pada Perusahaan Tambang Batubara yang Terdaftar di Bursa Efek Indonesia Periode 2013-2017. Masalah dalam perusahaan pertambangan batubara adalah keberadaan perusahaan yang memiliki peningkatan profitabilitas tetapi diikuti oleh peningkatan penghindaran pajak. Metode penelitian yang digunakan adalah analisis deskriptif dan verifikatif dengan pendekatan kuantitatif. Populasi dalam penelitian ini adalah 24 Perusahaan Penambangan Batubara yang Terdaftar di Bursa Efek Indonesia Periode 20132017. Sampel penelitian diambil dengan menggunakan metode purposive sampling untuk memperoleh 14 Perusahaan Tambang Batubara dengan 70 laporan keuangan pada periode 2013-2017. Metode analisis yang digunakan adalah analisis regresi linier sederhana. Hasil penelitian ini menunjukkan bahwa variabel profitabilitas yang diukur menggunakan Return on Asset (ROA) berpengaruh negatif dan signifikan terhadap Penghindaran Pajak yang diukur dengan menggunakan Tingkat Pajak Efektif (ETR).
\end{abstract}

Kata kunci: Profitabilitas, Penghindaran Pajak.

\begin{abstract}
This research is conducted to determine the influence of Profitability on Tax Avoidance in Coal Mining Companies Listed on The Indonesia Stock Exchange Period 2013-2017. The problem in the coal mining company is the existence of companies that have increased profitability but were followed by increased tax avoidance. The research method used is descriptive and verification analysis with a quantitative approach. The population in this study is 24 Coal Mining Companies Listed on The Indonesia Stock Exchange Period 2013-2017. Samples of research were taken using the purposive sampling method to obtain 14 coal mining companies with 70 financial statements in the period of 2013-2017. The analysis method used is multiple linear regression analysis. The result of this study showed that the profitability variables measured using Return on Asset (ROA) has negative and significant effect on Tax Avoidance which measured using Effective Tax Rate (ETR).
\end{abstract}

Keywords: Profitability, Tax Avoidance.

Naskah diterima: 18-05-2020, Naskah dipublikasikan: 30-11-2020

\section{PENDAHULUAN}

Pajak merupakan salah satu sumber pendapatan negara dan merupakan sumber pendapatan negara yang paling besar. Terhitung pada tahun 2015 hingga 2017, lebih dari 80\% pendapatan negara bersumber dari pendapatan perpajakan (Kementerian Keuangan Republik Indonesia).

Pajak seringkali dianggap sebagai beban oleh perusahaan dikarenakan akan mengurangi keuntungan perusahaan sehingga untuk meminimalisasi jumlah pajak yang harus dibayar, dilakukan perencanaan pajak (tax planning) Adhitya Himawan (2017). Perencanaan pajak bertujuan utama untuk mencari berbagai celah yang dapat ditempuh dalam koridor peraturan perpajakan (Pohan, 2013:14). Salah satu cara dari tax planning yaitu dengan melakukan penghindaran pajak (tax 
avoidance). Penghindaran pajak (tax avoidance) adalah rekayasa 'tax affairs' yang masih tetap berada dalam bingkai ketentuan perpajakan (lawful) (Suandy, 2011:7).

Salah satu faktor yang mempengaruhi penghindaran pajak adalah profitabilitas yang diukur menggunakan rasio return on assets (ROA). Semakin tinggi nilai ROA, maka akan semakin bagus performa perusahaan tersebut (Kurniasih \& Sari, 2013:58). Adanya rasio profitabilitas untuk mengukur seberapa besar kemampuan perusahaan memperoleh laba, baik dengan hubungan penjualan dan aset (Sri Dewi Anggadini, 2010). Lebih spesifik dijelaskan dalam penelitian Lim (2011) yang meyatakan bahwa tax avoidance merupakan salah satu cara penghematan pajak yang dilakukan dengan cara memanfaatkan ketentuan dan peraturan perpajakan yang dilakukan secara legal untuk meminimalkan kewajiban pajak yang harus dibayar. Jika kewajiban pajak minimal maka akan berdampak profitabiltas yang diperoleh perusahaan tersebut. Dengan adanya tax avoidance tentunya akan mempengaruhi penerimaan pajak, dimana penerimaan pajak ini telah direncanakan dan ditentukan dala APBN.

Yenny Sucipto sebagai Sekjen Forum Indonesia untuk Transparansi Anggaran (FITRA) mengatakan bahwa pengelakan pajak merupakan masalah yang serius di Indonesia. Diduga setiap tahunnya terjadi penghindaran pajak senilai Rp110 triliun. Kebanyakan penghindaran pajak tersebut dilakukan oleh badan usaha yang bergerak di sektor mineral dan batubara (Sucipto, 2017).

Selama lima tahun terakhir, tingkat penghindaran pajak pada perusahaan pertambangan batubara mengalami fluktuasi. Perusahaan dengan kode DEWA pada tahun 2015 sampai 2017 nilai profitabilitas mengalami peningkatan menjadi 0.125 pada tahun $2015,0.144$ pada tahun 2016 , dan 0.689 pada tahun 2017 tetapi diikuti dengan naiknya penghindaran perpajakan menjadi 0.914 pada tahun 2015, 0.801 pada tahun 2016, dan 0.744 pada tahun 2017.

\section{KAJIAN LITERATUR \\ Profitabilitas}

Menurut Kasmir (2016:196) menyatakan bahwa rasio profitabilitas adalah rasio untuk menilai kemampuan perusahaan dalam mencari keuntungan. Rasio ini juga memberikan ukuran tingkat efektivitas manajemen suatu perusahaan. Hal ini ditunjukan oleh laba yang dihasilkan dari penjualan dan pendapatan investasi. Senada yang disampaikan oleh Suad Husnan dan Enny Pudjiastuti (2015:76) menyatakan bahwa rasio ini dimaksudkan untuk mengukur seberapa jauh kemampuan perusahaan menghasilkan laba dari penjualannya, dari aset-aset yang dimilikinya, atau dari ekuitas yang dimilikinya. Selanjutnya Harahap (2009:304), profitabilitas merupakan kemampuan perusahaan mendapatkan laba melalui semua kemampuan dan sumber yang ada seperti kegiatan penjualan, kas, modal, jumlah karyawan, jumlah cabang dan sebagainya. Profitabilitas menurut Harahap (2009:459) dapat diukur dengan rasio Return on Asset (ROA) dengan membandingkan laba bersih sesudah pajak dengan total aktiva.

Rasio profitabilitas yang digunakan dalam penelitian ini adalah rasio profitabilitas dengan jenis Rasio Marjin Laba Bersih (Net Profit Margin). Karena menurut Pirmatua Sirait (2017:139) yang dapat disimpulkan bahwa Rasio Marjin Laba Bersih (Net Profit Margin) menggambarkan kemampuan perusahaan dalam menghasilkan laba bersih, yaitu laba bersih setelah pajak (EAT), rasio ini juga memberikan petunjuk bagi manajemen untuk alat pengukur yang paling baik untuk menetapkan profitabilitas perusahaan dan membantu mengukur secara menyeluruh efisiensi operasi dalam kesinambungan perusahaan.

\section{Penghindaran Pajak}

Rist \& Pizzica (2014:54) menyatakan:

"The effective tax rate explains the various rates at which a company's income is taxed as a result of different tax jurisdictions both domestically and internationally. Companies also employ strategies to minimize tax. To compute the effective (or average for the year) tax rate, total tax expense is divided by earnings before tax."

Menurut Rist \& Pizzica (2014:54), penghindaran pajak dapat diukur dengan menggunakan Effective Tax Rate (ETR) dengan cara membandingkan jumlah beban pajak dengan penghasilan 
sebelum kena pajak. Sedangkan menurut Chairil (2013:11) menyatakan bahwa penghindaran pajak adalah upaya mengefisienkan beban pajak dengan cara menghindari pengenaan pajak denan mengarahkannya pada transaksi yang bukan objek pajak. Dari beberapa definisi diatas dapat disimpulkan bahwa Penghindaran pajak adalah suatu kegiatan mengurangi atau menghilangkan beban pajak yang dibenarkan oleh peraturan perundang-undangan pajak terutama perencanaan pajak dengan memperhatikan ada atau tidaknya akibat-akibat pajak yang ditimbulkannya. Penghindaran pajak, bukan suatu hal yang dilarang namun dapat dilakukan untuk meminimalkan jumlaj pajak yang harus diselesaika oleh perusahaan tanpa bertentangan dengan aturan dan kebijakan yang berlaku.

Menurut Munawir (2012:33) profitabilitas menunjukkan kemampuan perusahaan untuk menghasilkan laba atau nilai hasil akhir operasional perusahaan selama periode tertentu. Maka diprediksi bahwa perusahaan yang mempunyai tingkat profitabilitas tinggi akan selalu menaati pembayaran pajak. Sedangkan perusahaan yang mempunyai tingkat profitabilitas rendah akan tidak taat pada pembayaran pajak perusahaan guna mempertahankan aset perusahaan daripada harus membayar pajak. ROA mengukur kemampuan perusahaan menghasilkan laba dengan menggunakan total aset (kekayaaan) yang dipunyai perusahaan setelah disesuaikan dengan biaya-biaya untuk mendanai aset tersebut (Deddy, 2016). Sedangkan menurut Kesit (2014) ROA berguna untuk mengukur sejauh mana efektivitas perusahaan dalam memanfaatkan seluruh sumber daya yang dimilikinya. ROA menggambarkan kemampuan manajemen untuk memperoleh keuntungan (laba). Hipotesis penelitian adalah sebagai berikut:

$\mathrm{H}_{1}$ : Profitabilitas berpengaruh terhadap penghindaran pajak.

\section{METODE PENELITIAN}

Metode penelitian yang digunakan dalam penelitian ini adalah metode penelitian deskriptif dan metode verifikatif dengan pendekatan kuantitatif. Variabel yang digunakan dalam penelitian ini adalah variabel bebas dan variabel terikat, penjelasannya sebagai berikut:

1 Variabel Bebas/Variabel Independen $\left(\mathrm{X}_{1}\right)$

Menurut Sugiyono (2017:39), variabel bebas merupakan variabel yang mempengaruhi atau yang menjadi sebab perubahannya atau timbulnya variabel dependen (variabel terikat). Variabel bebas atau variabel independen dalam penelitian ini yaitu Profitabilitas $\left(\mathrm{X}_{1}\right)$.

2 Variabel Terikat/Variabel Dependen (Y)

Sugiyono (2017:39) mendefinisikan variabel terikat sebagai variabel yang dipengaruhi atau yang menjadi akibat karena adanya variabel bebas. Variabel terikat atau variabel dependen dalam penelitian ini yaitu Penghindaran Pajak (Y).

Data yang digunakan dalam penelitian ini adalah data kuantitatif (data berupa angka). Jenis data yang digunakan dalam penelitian ini adalah data sekunder yang diperoleh dari laporan keuangan Perusahaan Pertambangan Batu Bara yang terdaftar di Bursa Efek Indonesia periode 2013 - 2017. Menurut Sugiyono (2017:224) teknik pengumpulan data merupakan langkah yang paling strategis dalam penelitian, karena tujuan utama dari penelitian adalah mendapatkan data. Teknik pengumpulan data yang digunakan dalam penelitian ini adalah:

1. Dokumentasi

2. Studi Kepustakaan (Library Research)

Menurut Sugiyono (2017:215) definisi dari populasi adalah wilayah generalisasi yang terdiri atas objek/subjek yang mempunyai kualitas dan karakteristik tertentu yang ditetapkan oleh peneliti untuk dipelajari dan kemudian ditarik kesimpulannya. Populasi dari penelitian ini adalah 120 laporan keuangan dari 24 Perusahaan Pertambangan Batu Bara yang terdaftar di Bursa Efek Indonesia tahun 2013 sampai dengan tahun 2017. Dalam penelitian ini, peneliti menggunakan penarikan sampel dengan kriteria tertentu (purposive sampling). Kriteria yang dipilih oleh penulis dalam menentukan penarikan sampel dalam penelitian ini adalah:

1. Perusahaan Pertambangan Batu Bara yang terdaftar di Bursa Efek Indonesia periode 20132017. 
2. Perusahaan Pertambangan Batu Bara yang terdaftar di Bursa Efek Indonesia yang mempublikasikan laporan keuangan yang telah diaudit dari tahun 2013-2017.

3. Perusahaan Pertambangan Batu Bara yang terdaftar di Bursa Efek Indonesia yang menggunakan mata uang US Dollar di laporan keuangannya.

\section{Metode Pengujian Data}

Menurut Ghozali (2011:57) uji asumsi klasik digunakan untuk mendapakan model regresi yang baik, terbebas dari penyimpangan data yang terdiri dari uji normalitas, uji multikolinearitas, uji heteroskedastisitas dan uji autokorelasi. Uji normalitas dilakukan untuk mengetahui apakah variabel dependen dan independent berdistribusi normal atau tidak. Pada penelitian ini digunakan uji satu sampel Kolmogorov-Smirnov untuk menguji normalitas model regresi. Dasar pengambilan keputusan dengan menggunakan Kolmogrov-Smirnov adalah:

- Jika nilai Asymp.sig > 0.1 maka data berdistribusi normal.

- Jika nilai Asymp.sig < 0.1 maka data tidak berdistribusi normal.

Uji multikolinieritas bertujuan untuk menguji apakah model regresi ditemukan adanya korelasi antar variabel bebas (independen). Dikatakan tidak terjadi multikolinieritas apabila nilai tolerance lebih besar dari 0,1 dan nilai VIF (Variance Inflation Factor) lebih kecil dari 10. Uji heteroskedastisitas dilakukan untuk mengetahui apakah dalam sebuah model regresi terjadi ketidaksamaan varians. Deteksi adanya heteroskedastisitas, yaitu dengan melihat ada tidaknya pola tertentu pada grafik scatterplot. Dikatakan tidak terjadi heteroskedastisitas apabila pada grafik scatterplot tidak ada pola yang jelas, serta titik- titik menyebar di atas dan di bawah angka 0 pada sumbu Y. Uji autokorelasi dilakukan untuk mengetahui apakah dalam sebuah model regresi linier terdapat hubungan yang kuat baik positif maupun negatif antara data yang ada pada variabel-variabel penelitian. Menurut Singgih Santoso (2010:219) pengambilan keputusan ada tidaknya autokorelasi adalah dengan cara melihat besaran Durbin-Watson (D-W) adalah sebagai berikut:

a. Jika D-W di bawah -2 berarti ada autokorelasi positif.

b. Jika D-W di antara -2 sampai +2 berarti tidak ada autokorelasi.

c. Jika D-W di atas +2 berarti ada autokorelasi negatif.

\section{Metode Analisis Data}

Dalam penelitian ini, analisis regresi linier sederhana digunakan untuk menguji seberapa besar pengaruh Profitabilitas terhadap Penghindaran Pajak Pertambangan Batu Bara yang Terdaftar di Bursa Efek Indonesia periode 2013-2017. Korelasi parsial digunakan untuk analisis atau pengujian hipotesis apabila peneliti bermaksud untuk mengetahui pengaruh atau hubungan variabel independen dengan dependen. Untuk mengetahui besarnya pengaruh Profitabilitas $\left(\mathrm{X}_{1}\right)$ terhadap Penghindaran Pajak (Y) dapat diketahui dengan menggunakan analisis koefisien determinasi atau disingkat Kd yang diperoleh dengan mengkuadratkan koefisien korelasinya.

Hipotesis penelitian ini dapat diterjemahkan dalam hipotesis statistik sebagai berikut:

Ho1: $\beta=0$ : Profitabilitas tidak berpengaruh terhadap Penghindaran Pajak

Ha1: $\beta \neq 0$ : Profitabilitas berpengaruh terhadap Penghindaran Pajak.

Jika menggunakan tingkat kekeliruan $(\alpha=0,1)$ untuk diuji dua pihak, maka kriteria penerimaan atau penolakan hipotesis yaitu:

1. Jika $t_{\text {hitung }} \geq t_{\text {tabel }}$ maka $\mathrm{H}_{0}$ ada di daerah penolakan, berarti Ha diterima artinya antara variabel bebas dan variabel terikat ada hubungannya.

2. Jika $t_{\text {hitung }} \leq \mathrm{t}_{\text {tabel }}$ maka $\mathrm{H}_{0}$ ada di daerah penerimaan, berarti Ha ditolak artinya antara variabel bebas dan variabel terikat tidak ada hubungannya. 


\section{HASIL DAN PEMBAHASAN \\ Hasil Penelitian}

Diketahui rata-rata profitabilitas Perusahaan Pertambangan Batu Bara yang terdaftar di Bursa Efek Indonesia Tahun 2013-2017 adalah sebesar 2,769, dengan nilai minimum sebesar -15,328 pada PT. Bumi Resources Tbk (BUMI) dan nilai maksimum sebesar 14,796 pada PT. Baramulti Suksessarana Tbk (BSSR). Nilai rata-rata penghindaran pajak Perusahaan Pertambangan Batu Bara yang terdaftar di Bursa Efek Indonesia Tahun 2013-2017 adalah sebesar 0,315, dengan nilai minimum sebesar -1,386 pada PT. Dian Swastika Sentosa Tbk (DSSA) dan nilai maksimum sebesar 2,768 pada PT. Bumi Resources Tbk (BUMI).

Hasil uji normalitas menunjukkan bahwa nilai Asymp.sig yang diperoleh yaitu 0,288 yang berarti lebih besar dari 0,1 yang menunjukkan bahwa data yang digunakan terdistribusi dengan normal. Nilai VIF variabel sebesar 1,085 lebih kecil dari 10 dan tolerance variabel bebas memiliki nilai sebesar 0,922 yang berarti lebih besar dari 0,1 maka dapat disimpulkan tidak terdapat multikolinieritas. Pada metode grafik scatter plot dihasilkan gambar dengan titik-titik yang diperoleh membentuk pola acak tidak beraturan serta menyebar di atas dan di bawah angka nol (0) pada sumbu $\mathrm{Y}$, sehingga dalam model regresi yang akan dibentuk tidak ditemukan adanya heteroskedastisitas. Nilai Durbin-Watson (DW) yang diperoleh sebesar 1,473. Karena nilai D-W berada di antara -2 sampai +2 berarti dapat dikatakan bahwa tidak terdapat adanya autokorelasi.

\section{Analisis Regresi Linier Sederhana}

$$
\mathrm{Y}=\mathbf{1 , 1 2 9}-\mathbf{0 , 0 2 2} \mathrm{X}_{1}
$$
berikut:

Dari hasil persamaan regresi linier sederhana di atas tersebut dapat diinterpretasikan sebagai

a. Konstanta sebesar 1,129 menunjukkan bahwa apabila variabel Profitabilitas sama dengan nol atau konstan, maka Penghindaran Pajak memiliki nilai sebesar 1,129 satuan.

b. Profitabilitas $\left(\mathrm{X}_{1}\right)$ memiliki nilai koefisien regresi sebesar $-0,022$. Hal ini menunjukkan bahwa jika Profitabilitas $\left(\mathrm{X}_{1}\right)$ mengalami peningkatan sebesar satu satuan, maka nilai variabel Penghindaran Pajak akan diprediksikan mengalami penurunan sebesar 0,022 satuan.

\section{Analisis Koefisien Korelasi}

Dapat dilihat pada tabel 1 mengenai regresi linear sederhana, sebagai berikut :

Tabel 1. Koefesien Determinasi

\begin{tabular}{|c|c|c|c|c|}
\hline Model & R & R Square & $\begin{array}{c}\text { Adjusted R } \\
\text { Square }\end{array}$ & $\begin{array}{c}\text { Std.Error of } \\
\text { The Estimate }\end{array}$ \\
\hline 1. &, $762(\mathrm{a})$ &, 580 &, 644 & 674283,95558 \\
\hline & & & & \\
\hline
\end{tabular}

a Predictors: (Constant), Profitabilitas

b Dependent Variable: Penghindaran Pajak

Berdasarkan hasil pengolahan data, koefisien korelasi antara Profitabilitas $\left(\mathrm{X}_{1}\right)$ terhadap Penghindaran Pajak (Y) sebesar 0.580, ini berarti terdapat hubungan yang sedang karena berkisar antara $0.400-0.599$.

\section{Pengujian Hipotesis}

Nilai $t_{\text {hitung }}$ yang diperoleh adalah sebesar $-5,475$. Dengan $\alpha=0,1$, $\mathrm{df}=\mathrm{n}-\mathrm{k}-1=62-2-1=59$, diperoleh nilai $t_{\text {tabel }}$ untuk pengujian dua pihak sebesar $\pm 1,671$. Dari nilai-nilai di atas terlihat bahwa nilai $t_{\text {hitung }}$ yang diperoleh sebesar $-5,475$ berada di luar nilai $t_{\text {tabel }}(-1,671$ dan 1,671$)$. Sesuai dengan kriteria pengujian hipotesis bahwa $\mathrm{H}_{0}$ ditolak dan $\mathrm{H}_{\mathrm{a}}$ diterima, artinya Profitabilitas berpengaruh terhadap Penghindaran Pajak pada Perusahaan Pertambangan Batu Bara yang terdaftar di Bursa Efek Indonesia periode tahun 2013-2017. 


\section{Pembahasan}

Hasil pengujian hipotesis menunjukkan bahwa terdapat pengaruh antara Profitabilitas terhadap Penghindaran Pajak. Terdapat hubungan yang negatif antara Profitabilitas terhadap Penghindaran Pajak di mana jika Profitabilitas naik maka Penghindaran Pajak akan mengalami penurunan. Besarnya pengaruh antara Profitabilitas terhadap Penghindaran Pajak sebesar 32,6\% dan sisanya $67,4 \%$ dipengaruhi oleh variabel-variabel lain yang tidak diteliti dalam penelitian ini seperti Ukuran Perusahaan, Corporate Governance, dan lain-lain. Profitabilitas dalam hal ini ROA digunakan untuk mengukur kemampuan perusahaan dalam menghasilkan laba berdasarkan asset yang dimilim perusahaan yang dikelola secara optimal. Semakin besar nilkai ROA secara otomatis semakin besar pula profitabilitas dari suatu perusahaan. Ketika perusahaan memiliki laba yang besar maka jumlah pajak penghasilanpun ikut meningkat sesuai dengan peningkatan profitabilitasnya, secara mendasar akan berupaya untuk melakukan pengurangan pajak agar beban pajak berkurang. serta Hal ini sejalan dengan penelitian terdahulu yang dilakukan oleh Wastam Wahyu Hidayat (2018), dan Shinta Budianti dan Khirstina Curry (2018) serta Tommy Kurniasih dan Maria M. Ratna Sari (2013) serta Winoto dan Indarti (2015) yang dalam penelitiannya menyebutkan bahwa profitabilitas berpengaruh negatif terhadap tax avoidance artinya semakin tinggi profitabilitas, maka semakin mengurangi tingkat tax avoidance suatu perusahaan yang disebabkan karena perusahaan dengan laba yang besar mampu untuk melakukan pembayaran pajak. Kondisi profitabilitas memiliki pengaruh negatif terhadap penghindaran pajak artinya semakin tinggi profitabilitas maka perusahaan akan selalu mentaati pembayaran pajak.

\section{PENUTUP}

Profitabilitas berpengaruh terhadap Penghindaran Pajak pada Perusahaan Pertambangan Batu Bara yang terdaftar di Bursa Efek Indonesia Tahun 2013-2017. Profitabilitas memiliki pengaruh negatif terhadap Penghindaran Pajak di mana meningkatnya Profitabilitas akan diikuti dengan penurunan tingkat Penghindaran Pajak. Hal tersebut dikarenakan semakin tinggi profitabilitas perusahaan berarti semakin tinggi kemampuan perusahaan untuk membayar beban pajak yang terutang sehingga tingkat penghindaran pajak akan menurun.

\section{REFERENSI}

Adhitya Himawan. 2017. Fitra: Setiap Tahun, Penghindaran Pajak Capai Rp110 Triliun, [online], (https://www.suara.com/bisnis/2017/11/30/190456/fitra-setiap-tahun-penghindaran-pajakcapai-rp110-triliun), diakses tanggal 15 Maret 2019)

Chairil Anwar Pohan. 2013. Manajemen Perpajakan: Strategi Perencanaan Pajak dan Bisnis. Jakarta: PT. Gramedia Pustaka Utama.

Deddy Dyas Cahyono, Rita Andini dan Kharis Raharjo. 2016. Pengaruh Komite Audit, Kepemilikan Institusional, Dewan Komisaris, Ukuran Perusahaan (Size), Leverage (DER) dan Profitabilitas (ROA) terhadap Tindakan Penghindaran Pajak (Tax Avoidance).

Erly Suandy. 2011. Perencanaan Pajak. Jakarta: Salemba Empat.

Imam Ghozali. 2011. Aplikasi Analisis Multivariate Dengan Program SPSS. Semarang: Badan Penerbit Universitas Diponegoro.

Kasmir. 2016. Analisis Laporan Keuangan. Jakarta: Rajawali Pers.

Kesit Bambang Prakosa. 2014. Pengaruh Profitabilitas, Kepemilikan Keluarga dan Corporate Governance Terhadap Penghindaran Pajak Di Indonesia.sSNA 17 Mataram.9

Laporan Tahunan Pajak, diakses pada 17 Oktober 2018 dari www.kemenkeu.go.id

Lim, Y. D. 2011. Tax avoidance, cost of debt and shareholder activism: Evidence from Korea. Journal of Banking \& Finance 35, 456-470.

Pirmatua Sirait. 2017. Analisis Laporan Keuangan. Yogyakarta: Ekuilibria.

Rist, Michael \& Pizzica, Albert J. 2015. Financial Ratios for Executives: How to Assess Company Strength, Fix Problems, and Make Better Decisions. New York: Apress.

S. Munawir. 2012. Analisis Laporan Keuangan. Yogyakarta: Liberty. 
Shinta Budianti dan Khirstina Curry. 2018. Pengaruh Profitabilitas, Likuiditas, dan Capital Intensity Terhadap Penghindaran Pajak (Tax Avoidance). Seminar Nasional Cendekiawan 4, Jakarta. ISSN (P): $2460-8696$.

Singgih Santoso. 2010. Statistik Parametrik: Konsep dan Aplikasi Dengan SPSS. Jakarta: PT. Elex Media Komputindo.

Sofyan Syafri Harahap. 2009. Analisis Kritis Atas Laporan Keuangan. Jakarta: PT Raja Grafindo Persada.

Sri Dewi Anggadini. 2010. Analisis Fee Based Income Dampaknya Terhadap Profitabilitas (Studi Kasus Pada PT. Bank Negara Indonesia (Persero) Tbk. Jurnal Bisnis, Manajemen \& Ekonomi Vol. 9 No.9, ISSN: 1693-8305.

Suad Husnan Enny Pudjiastuti. 2002. Dasar-Dasar Manajemen Keuangan Edisi Ketiga. Yogyakarta: Akademi Manajemen Perusahaan YKPN

Sugiyono. 2017. Metode Penelitian Kuantitatif, Kualitatif, dan R\&D. Bandung: Alfabeta.

Tommy Kurniasih dan Maria M. Ratna Sari. 2013. Pengaruh Return on Assets, Leverage, Corporate Governance, Ukuran Perusahaan Dan Kompensasi Rugi Fiskal Pada Tax Avoidance. Jurnal Ekonomi. https://doi.org/10.1016/j.giq.2005.05.002

Wastam Wahyu Hidayat. 2018. Pengaruh Profitabilitas, Leverage Dan Pertumbuhan Penjualan Terhadap Penghindaran Pajak: Studi Kasus Perusahaan Manufaktur di Indonesia. Jurnal Riset Manajemen Dan Bisnis (JRMB) Fakultas Ekonomi UNIAT, 3(1), 19-26. P-ISSN 25277502 E-ISSN 2581-2165.

Winoto dan Indarti, Iin. 2015. Pengaruh Profitabilitas, Leverage dan Ukuran Perusahaan terhadap Penghindaran Pajak. Universitas Negeri Malang. 